\title{
Micro Health Project
}

\author{
Khadka A*, Sharma S, Regmi S, Chapagain S, Lamichhane B, Baral S, Thapa P, Ankur KC, \\ Thapa A, Mandal B, Khadka P, Poudel A, Khanal S, Shrestha U \\ MBBS 3rd year, Gandaki Medical College \& Teaching Hospital, Pokhara, *Group Leader
}

\author{
Keywords \\ Community health diagnosis, \\ Micro health project, Prioritization. \\ Corresponding author \\ Dr. Ajay Khadka, MBBS 3rd year, \\ Gandaki Medical College \& Teaching \\ Hospital, pokhara, Nepal \\ Email: ajaykhadka1995@gmail.com
}

\begin{abstract}
Community health diagnosis is a comprehensive assessment of health status of the community in relation to its social, physical and biological environment. The purpose of community health diagnosis is to define existing problems, determine available resources and set priorities for planning, implementing and evaluating health action, by and for the community.
\end{abstract}

The community health diagnosis program began on $4^{\text {th }}$ September 2015 and continued till $13^{\text {th }}$ September 2015 in ward no 1 and 5 Rupakot VDC, Kaski, Nepal. The program was organized in following phases: data collection, data analysis, first community presentation, prioritization of need and planning of micro health project (MHP), implementation and evaluation of MHP, and final community presentation.

On the basis of the observed and the felt needs of the community, we found the real needs and prioritized them as follows.

For community: Proper water purification, information about common diseases, KAP on diseases, knowledge on TB and DOTS.

For school-going children: Education on environmental sanitation, education on personal hygiene - teeth brushing and hand washing, adolescent health education.

We launched micro health project (MHP) on these topics, conducting school-based as well as community-based programs.

\section{INTRODUCTION}

Community health diagnosis, the very first exposure of first year medical students with the community people, is in fact one of the best practical-oriented learning periods in medical life.

The community health diagnosis program began on $4^{\text {th }}$ September 2015 and continued till 13 ${ }^{\text {th }}$ September 2015 in ward no. 1 and 5 Rupakot VDC, Kaski. The program was organized in the following phases:

- Data collection

- Data analysis

- First community presentation

- Prioritization of need and planning of micro health project (MHP)
- Implementation and evaluation of MHP

- Final community presentation

We visited houses, interviewed, discussed with the community people, conducted free health camp, participated in community functions, attempted to sort out the health problems and did MHP on the basis of available resources. We took a little step, which might not have solved much of the problems. We don't expect our small steps to bring any radical changes. Our study and report may help the planner and administrative person to prioritize the real needs in planning of the village developmental works.

Rupakot VDC ward no. 1 and 5 governed 192 houses and a total population of 1164 . Though Muslims and Gurungs are the major ethnic groups, the main religions are 
Muslim and Hindu. CBR and CDR are 2.74 per thousand and 9.45 per thousand respectively, which are both lower than the national figure. PGR is $3.55 \%$ per annum. Thus, the population doubling time is 19.7 years. Median age of the population is 24.1 years.

The total literacy rate is $69 \%$. About $17 \%$ and $8.3 \%$ of people smoke and drink respectively. The rates are particularly higher in indigenous and underprivileged communities according to our HH survey. Agriculture is the main occupation about $52 \%$ of the people executed it, followed by $24 \%$ that rely on foreign employment.

Majority of people (92\%) preferred health institutions as their first place of treatment, which may owe to the easy accessibility to the only sub-health post. Most of the women were provided ANC though only $27 \%$ of deliveries were conducted at health institutions.

Immunization and nutritional status of children is good as malnutrition is not prevalent according to both Gomez and IAP classification.

The knowledge, attitude and practice (KAP) of the people were found to be satisfactory. Out of 200 household respondents, 142 responded to lack of cleanliness as the cause of diseases. About $84.29 \%$ of respondents had heard about diarrhea, and a majority of $74.54 \%$ explained the proper way of preparing Jeevanjal. Seventy five percent of the total respondents were familiar with worm Infestation and $79.5 \%$ of people have heard about typhoid. More than $50 \%$ of the people have heard about HIV/ AIDS (63.68\%), goitre (66.67\%) and TB (53.36\%). However, maybe because of the lack of TB patients, only $8 \%$ of the people know about the treatment of TB i.e. directly observed treatment short-course (DOTS). This rate was low for malnutrition, where only $42.5 \%$ of the people were found to have heard of it. After analyzing, joint pain, typhoid and gastritis were found as the top three diseases.

On the basis of the observed and the felt needs of the community, we found the real needs and prioritized them as:

\section{For community people:}

- Proper water purification

- Information about common diseases

- $\quad$ KAP on diseases

- Knowledge on TB and DOTS

For school-going children:

- Education on environmental sanitation
- Education on personal hygiene: Teeth brushing and hand washing

- Adolescent health education

We launched micro health project (MHP) on these topics, conducting school-based as well as community-based programs.

To sum up, Rupakot (Ward no 1 and 5) is taking gradual steps towards awareness and development. Despite the dark clouds of ignorance and superstitious beliefs among the uneducated and underprivileged people, there exists a silver lining of education among the newer generations. Those who are already aware must themselves adopt a healthy behavior and should persuade others for the same. Only the combined effort of all the people can help Rupakot make a significant advancement towards attaining 'Panacea'-a state of complete health.

\section{MICRO HEALTH PROJECT}

Micro health project (MHP) is a small scale project that is planned, implemented and evaluated in the community setting to minimize the prominent health problems within limited resources and time.

MHP is a short term project designed to develop the health related awareness, skills and self reliance among the people on the priority basis of real needs involving resources with their maximum use.

The three phases of conduction of MHP:

- Planning and preparation

- Implementation

- Evaluation

\section{PLANNING AND PREPARATION}

Planning is the process of identifying key objectives and choosing alternative ways to accomplish a determined purpose. It was done in following steps.

1. Defining objectives and target groups

2. Resources collection

3. Fixing date and place for the implementation

\section{Needs}

During our community health diagnosis field visit, we observed various needs in that community (Observed needs) and through the focus group discussions and interviews, we found about their felt needs. Then by discussing with the community leaders at focus group 
discussion and first community presentation, we came to conclude the real needs of the community.

Table 1: The observed, felt and real needs of the community

\begin{tabular}{|c|c|c|}
\hline Observed needs & Felt needs & Real needs \\
\hline $\begin{array}{l}\text { Health education on } \\
\text { environmental sanitation }\end{array}$ & Road & $\begin{array}{l}\text { Examination of purity of water } \\
\text { and knowledge to treat water }\end{array}$ \\
\hline Safe drinking water & $\begin{array}{l}\text { Drinking } \\
\text { water }\end{array}$ & $\begin{array}{l}\text { Knowledge about personal } \\
\text { cleanliness }\end{array}$ \\
\hline $\begin{array}{l}\text { Knowledge on various } \\
\text { diseases }\end{array}$ & $\begin{array}{l}\text { Health } \\
\text { service }\end{array}$ & $\begin{array}{l}\text { Health awareness on environ- } \\
\text { mental sanitation }\end{array}$ \\
\hline Health services & School & Knowledge on common diseases \\
\hline Sanitation & $\begin{array}{l}\text { Higher } \\
\text { education }\end{array}$ & $\begin{array}{l}\text { Maternal and child health educa- } \\
\text { tion }\end{array}$ \\
\hline \multirow[t]{3}{*}{ Water } & Irrigation & \\
\hline & $\begin{array}{l}\text { Agricultural } \\
\text { development }\end{array}$ & \\
\hline & Employment & \\
\hline
\end{tabular}

\section{RATIONAL FOR SELECTION OF MHP}

\section{Drinking purified water}

$83.3 \%$ of respondents drink water without any form of purification.

\section{Hand washing}

More than $50 \%$ of children didn't know the steps of hand washing.

\section{Brushing teeth}

$29 \%$ of elderly and around $40 \%$ of children were not brushing teeth twice a day.

\section{BASIS OF PRIORITIZATION}

1. Limited resources and time

2. Limited knowledge

3. Willingness / interest of the target group

4. Sustainability

5. Cost-effectiveness

6. Magnitude and severity of the problem

7. Availability of the target group

Table 2: Basis of prioritization

\begin{tabular}{|c|c|c|c|c|c|}
\hline $\begin{array}{l}\text { Teeth } \\
\text { brush- } \\
\text { ing and } \\
\text { hand } \\
\text { wash- } \\
\text { ing }\end{array}$ & $\begin{array}{l}\text { Envi- } \\
\text { ron- } \\
\text { mental } \\
\text { sanita- } \\
\text { tion }\end{array}$ & $\begin{array}{l}\text { Ado- } \\
\text { lescent } \\
\text { health } \\
\text { educa- } \\
\text { tion }\end{array}$ & $\begin{array}{c}\text { Knowl- } \\
\text { edge } \\
\text { on TB } \\
\text { and } \\
\text { DOTS }\end{array}$ & $\begin{array}{c}\text { Safe } \\
\text { drink- } \\
\text { ing } \\
\text { water }\end{array}$ & $\begin{array}{c}\text { KAP } \\
\text { on } \\
\text { dis- } \\
\text { eases }\end{array}$ \\
\hline
\end{tabular}

\begin{tabular}{|c|c|c|c|c|c|c|}
\hline $\begin{array}{l}\text { Resourc- } \\
\text { es }\end{array}$ & ++ & - & ++ & + & + & + \\
\hline $\begin{array}{l}\text { Our } \\
\text { knowl- } \\
\text { edge }\end{array}$ & ++ & + & ++ & + & ++ & ++ \\
\hline $\begin{array}{l}\text { Target } \\
\text { group }\end{array}$ & ++ & ++ & + & + & ++ & + \\
\hline $\begin{array}{l}\text { Sustain- } \\
\text { ability }\end{array}$ & + & + & + & + & ++ & + \\
\hline $\begin{array}{l}\text { Cost } \\
\text { effective- } \\
\text { ness }\end{array}$ & + & + & + & + & + & ++ \\
\hline $\begin{array}{l}\text { Magni- } \\
\text { tude of } \\
\text { the prob- } \\
\text { lem }\end{array}$ & ++ & + & + & + & + & + \\
\hline $\begin{array}{l}\text { Sever- } \\
\text { ity of the } \\
\text { problem }\end{array}$ & ++ & - & ++ & + & ++ & + \\
\hline Total +/- & $12 / 0$ & $6 / 2$ & $10 / 0$ & $7 / 5$ & $11 / 0$ & $9 / 0$ \\
\hline Rank & 1 & 6 & 3 & 5 & 2 & 4 \\
\hline
\end{tabular}

The above Table 2 is the prioritization matrix. Here we have given the positive sign "+" and "-" signs to determine which health problem needs immediate attention and can be achieved. Here, we can easily see that teeth brushing and hand washing, safe drinking water and adolescent health education received the maximum + signs thus were categorized as the prioritized needs. On the basis of prioritization table, the following MHP topics were selected and then grouped under community and school based.

Table 3: Planning and implementation

\begin{tabular}{|c|c|c|c|}
\hline & $\begin{array}{l}\text { Target } \\
\text { group }\end{array}$ & Activities & Evaluation \\
\hline $\begin{array}{l}\text { Safe drinking } \\
\text { water }\end{array}$ & $\begin{array}{l}\text { Community } \\
\text { people }\end{array}$ & $\begin{array}{l}\text { Demonstration } \\
\text { of SODIS and } \\
\text { charts }\end{array}$ & $\begin{array}{l}\text { Feed back and } \\
\text { questionnaire }\end{array}$ \\
\hline $\begin{array}{l}\text { Teeth brushing } \\
\text { and hand } \\
\text { washing }\end{array}$ & $\begin{array}{l}\text { Primary and } \\
\text { secondary } \\
\text { students }\end{array}$ & $\begin{array}{l}\text { Demonstration } \\
\text { by using pie- } \\
\text { charts, graphs } \\
\text { and role play }\end{array}$ & $\begin{array}{l}\text { Competition and } \\
\text { observation }\end{array}$ \\
\hline
\end{tabular}

\section{IMPLEMENTATION}

As shown in the above figure, after completing the planning of our MHP we concluded to carry out the MHPs on: i) Safe drinking water and ii) Teeth brushing and hand washing.

As per the planning, to implement MHP

(i) We demonstrated the SODIS method of water purification and presented various water purification 
techniques with the help of charts and posters to a large mass of people.

(ii) Secondly, we demonstrated the correct method of brushing teeth and the steps of hand washing to the school students of primary and secondary level. Also, we had prepared charts with lots of drawings that we stuck to their classroom walls for future reference.

\section{EVALUATION}

After conducting the MHP, we questioned the community people and the children to make sure that they had understood the message we were trying to convey. We also conducted competitions and observations to know how much of the learnt knowledge was being implemented by the people. Also, we understood that the sudden change in water purification may not be possible so we will conduct follow-up programs in the upcoming years to ensure that the methods we taught are being implemented.

\section{CONCLUSIONS}

Our ten days stay at the village was an eagle's eye to reveal its minute status. We had chance to put our theoretical knowledge into practice which was much harder than our expectations. Anyway, we learnt to overcome the hardships and achieve the target. Unity in diversity was the main theme in our group. Though being from different nook of the country with different opinion and abstract idea, a thought of learning together was always present in our heart. Whenever any conflict arose, we tried our best to solve it. We learnt to tackle with those people who were completely new to us. In the unfamiliar place, we ourselves learnt to seek help in many regards. The village appeared to be a desert and we turned ourselves as cactus, just adapted to the harsh situations and miseries of village life. We learnt to be acquainted with the problems due to sharp geographical variations. We learnt to respect and appreciate others. We got an opportunity to see, hear, touch, taste and feel the Nepalese village life.

Our community health diagnosis was of 10 days but it was love of people and the entire Bhirchowk that it passed like a moment to treasure through all our life.

First few days were difficult to cope up. An entire new ambience created around us, a complete new world for us. However it didn't create a hurdle for long. People were so candid, cooperative and helpful that we couldn't prevent ourselves from melting and molding in Bhirchowk's way. Bhirchowk and its people entirely lured us.

Nonetheless, we, medical students, learnt a lot and are really benefitted by CHD. We are indebted to the whole community, villagers and department of community medicine for this opportunity.

\section{REFERENCES}

1. K. Park. Park's Text Book of Preventive and Social Medicine. 22 edition. Banarsidas publishers, Jabalpur (MP), India 2013

2. Sunder Lal, Adarsh, Pankaj. Text book of community medicine. Preventive and Social Medicine, CBS publishers. 2011

3. Lalita D, Hiremath, Dhananjaya A, Hiremath. Essentials of Community Medicine : A practical approach. Jaypee. 2010.

4. Subramanian Mangala. Hand Book of Community Medinine, Jaypee. 2012 